During the years 1948 to 1950 he was Chairman of four working parties set up to advise the Minister of Health on the average times taken by dispensing pharmacists, dental practitioners, ophthalmic medical practitioners and ophthalmic opticians in the carrying out of their duties. This work, which involved sampling over a wide area of England, Wales and Scotland, he found of absorbing interest.

By virtue of association with his family's old-established business as paper merchants, Penman became a member of the Stationers' and Newspaper Makers' Company of which he was Master in 1955 . He served for some years as a Governor of the Stationers' Company's School.

In retirement Penman devoted much of his time to the affairs of the British Home and Hospital for Incurables, serving for 18 years as a member of the Board of Management and of the House Committee and Finance Committee and as Chairman of the Board from 1960 to 1967 . He also set aside practically every Friday afternoon for the Warlingham Over-60's Club of which he was for many years the Chairman. It was his practice to make several journeys before and after each meeting conveying members to and from the Club in the large Rolls Royce which he delighted to drive. This he continued to do until a few months before his death and he would often refer with affection and admiration to the fortitude of his 'old people' most of whom were about 20 years his junior!

In his Presidential Address Penman also said:

It is also a good thing . . . for a man to keep up his games and outdoor pursuits as long as possible. A healthy body is a great asset if a man be called upon to work hard and carry heavy responsibilities; it is also a great assistance towards a clear mind.

Here again he practised what he preached. As a young man he was a keen athlete and tennis player and it was only in middle life that he turned his attention to fencing, ski-ing, ice skating and horse riding. Until about 2 years before his death he rode his horse daily, if possible, and usually before breakfast. He ceased to do so only when the horse, which he had broken-in many years previously, was obliged to give up on account of old age!

William Penman worked hard, played hard and carried heavy responsibilities but, thanks to his rigorous self-discipline, he preserved until the day of his death the healthy body and the clear mind, the energy and the enthusiasm, which enabled him to live a full and active life so much of which was dedicated to the service of others. He will long be remembered by many with gratitude and affection for the man he was and for the things he did.

S. F. ISAAC

\title{
WILFRED PERKS
}

Wilfred Perks was born on 3 October 1902 and died on 19 March 1970. This was an eventful period in history when changes were taking place in many aspects of society. Wilf was a participator who reacted to the world around him with curiosity in his mind and concern in his heart. And when it came to his own sphere of the actuary, he also reacted with great energy. The actuarial profession of 1970 is very different from 1930 , both in what it does and in the way it thinks and Wilf was always a prominent influence in this evolution.

To those in the future who read his formal contributions to the Journal it will be apparent enough why he was given a gold medal - the honour he treasured above all others. To those who go further and read his many contributions to the discussions some 
glimpse will be seen of Wilf's trenchancy and universality of interest. To those who go further still and delve into meetings in the Institute, in the Life Offices' Association and the Industrial Life Offices' Association for a period of more than 30 years, some idea will be given of his force of personality and stature of mind.

But the full man is not to be found in the written words, impressive though they are. In some ways, a glimpse of him making his purposeful way down Holborn would tell you more. He was below average height, partly because of an appreciable spinal curvature. Though this never seemed to worry him, and was a fact which one soon forgot on acquaintance, it did affect his physical stance. Never, for Wilf, the downcast eye or sidelong glance; everything and everybody, friend and foe, was to be faced eye to eye. Because of the curvature, his head was held forward and upward, so that his jaw was very much in front of his body. Topped with a good head and fearless eyes, it was an impressive appearance and if the eyes hardened and the jaw projected still further, as happened at any hint of duplicity, then it could be truly formidable.

But within this forceful, energetic exterior, there was warmth and humour. He had a classical mind, but a romantic heart and, as so often, it was this dualism which was fertile of inspiration and contributed to the many sides of his nature. For example, he combined the thorough analytical mind of the scholar with the ardour of the reformer. Over and over again he would prove in committee to have both the most detailed knowledge of the facts and the widest view of the social context into which those facts had to be fitted.

Wilf was more than a little of a rebel. He hinted at times of serious unhappiness in his youth and, in later years, life was not as kind or as fair to him as it might have been. One of his deepest convictions was that power corrupts and he was a little too ready to attribute guile to the muddled motives of weaker humanity. This was strange, in a way, because he himself was a denial of these generalities. He was incapable of guile and, when in later years he chaired a number of committees, he was invariably tolerant, patient and just. Authority mellowed Wilf, rather than corrupted him.

The main outlines of his career are given at the end, but it is difficult in a memoir of this nature to descend from the general to the particular, because Wilf's greatest asset was the universality of his interest. Taking the whole spectrum of actuarial theory, he was the leader of his generation. His 1931 modification of the Makeham formula is still the most effective tool in this area. His 1947 paper on Inverse Probability, though he later regarded it as abortive, was an imaginative excursion into the nature of ignorance from which all judgments must spring. This paper was symptomatic, because although he could be very emphatic in the cut and thrust of debate, in the quiet of his own mind he had an acute sense of human fallibility and the limitations of reason-including his own. This gave him a healthy scepticism about fashionable theories whether they be concerned with demography, economics, cosmology or anything else. He was not always right, but in total he was a lavish and highly successful investor in human ideas.

This combination of a zest for theory and a keen sense of realism, made him an outstanding practical actuary. To these natural aptitudes must be added his great experience. He joined the Pearl Assurance Company-where he remained till retirement-at the age of 17. He qualified as a Fellow before he was 21 and was given an official post before he was 30 . Since the Pearl transacts all forms of assurance, and some of them overseas, Wilf was treading many corridors of managerial thought at a very early age. He thus became a leading expert in all aspects of life assurance (apart from group pension business) and he was probably the best authority in the country on industrial life assurance. Two examples will illustrate Wilf's range of sense and sensibility. A net premium valua- 
tion was an instrument which he understood intimately and he had a sensitive ear for its tones and overtones. He had no patience with those who condemned it without even understanding its shortcomings. He was a wise and experienced life office navigator. At the other end of the spectrum, he could be a true statesman. On an intensely political subject like national pensions, he had too good a head to follow the political emotionalists, but too warm a heart to follow the academic theorists. All his friends could add other examples.

One of Wilf's many endearing features was his loyalty. Though he was ardent in pursuit of what he felt to be right, utterly regardless of personal self-interest, he was always tender of the interests of those he represented, be it his profession, his industry or his Company. Whether this loyalty was fully appreciated may be doubted. Certainly, his inability to dissemble in his own interest on occasion cost him friends-though usually temporarily. This is not the cheap and easy way to success and the verdict of retrospection now that he is gone, may well be that his own generation under-honoured him. May succeeding generations do better.

Wilf was fond of music and his favourite composer was Beethoven. This was as it should be, because they had much in common. Beethoven can at times be over-emphatic, but he has that rare gift of imagination which sees things as a whole and, by unifying, enlarges experience.

This memoir would be seriously deficient if mention were not made of Wilf's deep regard for womenfolk. He was always devoted to his first wife, Peggy, until her premature death in 1957. He later found great happiness with his second wife, Pam, and her children; and they loved 'Willy' (a nickname of which he was extremely proud). After his retirement in January, 1967, his cheeks took on a country apple-glow of outer and inner health and it was a fine autumn to a great life. It was sadly brief.

F. M. REDINGTON

Curriculum Vitae (3 October 1902-19 March 1970)

\section{Education}

Plymouth College

\section{Occupation}

Pearl Assurance Company:

Assistant Actuary 1932-48.

Joint Actuary 1948-59.

Actuary 1959-67.

\section{Public Committee}

Chairman of the Home Office Committee on Criminal Statistics, which reported in September 1967.

\section{Institute of Actuaries}

Fellow 1923.

Member, Board of Examiners 1932-36.

Member of Council for 14 years between 1940 and 1958.

Honorary Secretary 1945-47.

Vice-President 1949-52.

Awarded a Gold Medal in 1964. 


\section{Papers submitted to the Institute}

'On some Experiments in the Graduation of Mortality Statistics' (December 1931).

'On a modification of the net premium method of valuation of participating assurances and on the application of the $n$-ages method to the valuation of assurances grouped by years of entry and to the approximate calculation of isolated values of actuarial functions' (February 1933).

'Two-Variable Developments of the $n$-Ages Method' (March 1945).

'Some Observations on Inverse Probability including a new Indifference Rule' (January 1947).

'The Treatment of Sub-Standard Lives in Practice' (February 1952).

'A Consistent System of Investment and Bonus Distribution for a Life Office' (jointly with G. V. Bayley. November 1952).

Numerous contributions to discussions, etc., recorded in J.I.A. and other publications, book reviews and other contributions.

\section{Publication}

Mortality and Other Investigations, Vol. 1 (jointly with H. W. Haycocks in 1955).

\section{Clubs}

Denarius Club. Founder member 1923 (Chairman 1951).

Fellowship Club, elected 1934.

Gallio Club, elected 1944.

Actuaries' Club, elected 1946.

\section{RONALD GORDON BARLEY}

RONALD GORDON BARLEY died on the 13 February 1970, aged 56, after a short illness. Having decided on an actuarial career whilst still at Dulwich College, he specialized for his final 2 years in mathematics and passed Part I of the Institute Examinations whilst still there. Qualification as a Fellow followed in 1939.

He always maintained that every actuary owed much to his profession and never spared himself when called upon to serve the Institute in whatever capacity. From 1945 to 1949 he was a Tutor. This work he carried out most competently as the writer can testify from personal experience. Not only were his comments on test papers particularly helpful but he also arranged regular meetings with his students at a time when this was by no means a regular practice. In 1949 he became an Examiner and continued in this capacity until 1955. In 1953 he was elected a member of Council serving until 1959. In 1955 he became Chairman of the Armorial Bearings Committee when Letters Patent granting the Institute's Armorial Bearings were obtained. It was typical that to assist him in this task he made a careful study of heraldry and prepared the first design of the Coat of Arms himself. While engaged on this work he was also Joint Honorary I ihrarian, a position which he held from 1951 to 1957 . During his period in this office the library was transferred to its new home in the rebuilt Staple Inn and decimal classification was introduced, tasks which inevitably threw a heavy burden on the Librarians at the time. From 1957 to 1959 he was Honorary Secretary. In 1962 he took on the duties of Chairman of the Appointments Board and held this position for 4 years.

$\mathrm{He}$ contributed a short but original paper to the proceedings of the Institute of Actuaries Centenary Assembly in 1948 entitled 'Mortality ABC'. This paper drew attention to the need for collaboration between actuaries and biologists in developing 